\title{
Underestimated scale of songbird offshore migration across the south-eastern North Sea during autumn
}

\author{
Vera Brust $^{1}$ (D) Ommo Hüppop ${ }^{1}$
}

Received: 3 May 2021 / Revised: 11 September 2021 / Accepted: 27 September 2021 / Published online: 13 October 2021

(c) The Author(s) 2021

\begin{abstract}
Flights over open water can be challenging for migrating songbirds. Despite numerous observations of songbirds migrating over remote islands, virtually nothing is known about the proportion of songbirds risking to fly offshore rather than to follow the coastline. By means of large-scale automated radio-telemetry, we individually tracked songbirds during their autumn migration through the German Bight area in the south-eastern North Sea. Our tracking network facilitated the recording of movement patterns over the bay and, for the first time, the estimation of the proportions of individuals embarking on offshore flights from their coastal stopover sites. Our data are consistent with previous observations of decreasing migration densities from nearshore to offshore, i.e. from east to west in autumn. Still, we revealed a considerable proportion of $25 \%$ of birds flying offshore. The tendency to fly offshore decreased from west to south migrants, which is in line with optimal bird migration theory. Among south-west migrating species, which also comprise the vast majority of songbird species migrating through the German Bight area, thrushes showed the highest proportions of offshore flights. Considering the recent and ongoing increase of artificial offshore structures, our results suggest that some species or species groups might especially face an increased risk of being negatively affected.
\end{abstract}

Keywords Songbirds $\cdot$ Radio-telemetry $\cdot$ Bird migration $\cdot$ Offshore $\cdot$ North sea

\section{Zusammenfassung}

Das unterschätzte Ausmaß des Herbstzuges von Singvögeln über der südöstlichen Nordsee

Das Überfliegen der offenen See stellt für Singvögel eine Herausforderung dar. Obwohl sie jedes Jahr in großer Zahl über Inseln ziehend beobachtet werden, ist bisher kaum etwas über die jeweiligen Anteile der Populationen, welche den südöstlichen Teil der Nordsee direkt queren bzw. entlang der Küste fliegen, bekannt. Mithilfe eines Netzes automatisierter Radiotelemetrie-Empfangsstationen konnten wir besenderte Singvögel im Bereich der Deutschen Bucht individuell verfolgen. Unser Netzwerk ermöglichte die Aufzeichnung von Bewegungsmustern und erstmals auch eine Abschätzung, welche Anteile von an der Küste markierten Individuen über das offene Meer weiterziehen. Unsere Ergebnisse bestätigen eine generelle Abnahme der Zugintensität von der Küste zum offenen Meer, also im Herbst von Ost nach West. Trotzdem wählte ein Viertel der telemetrierten Vögel den Weg über das offene Meer. Der Anteil der Flüge über See nahm von süd- zu westziehenden Arten hin ab. In der Gruppe der Südwestzieher, welche den größten Anteil der durch die Region ziehenden Vögel repräsentiert, flogen bei den Drosseln die höchsten Anteile über das offene Meer. Unsere Ergebnisse lassen bei einigen Arten und Artengruppen ein erhöhtes Risiko einer Beeinträchtigung durch bereits vorhandene und noch geplante OffshoreBauwerke vermuten.

Communicated by N. Chernetsov.

Vera Brust

vera.brust@ifv-vogelwarte.de

1 Institute of Avian Research "Vogelwarte Helgoland", An der Vogelwarte 21, 26386 Wilhelmshaven, Germany

\section{Introduction}

Animal migrations are profoundly influenced by topography, i.e. by the location and configuration of the Earth's land and water masses. Ocean or mountain barriers and weather systems are obvious constraints on migration routes (Chapman 
et al. 2014; La Sorte and Fink 2017; Nilsson et al. 2019). During their migratory journeys, many flying animals have to cross-or alternatively to circumvent-unsuitable habitats, such as deserts (Dolnik 1990; Schmaljohann et al. 2007; Klaassen et al. 2014), large bodies of water (e.g. Williams and Williams 1990; Cohen et al. 2017; Zenzal et al. 2021), or high mountains (Lack and Lack 1951; Bruderer and Jenni 1990; Nilsson et al. 2019). For migrating land birds, flying over open water can be particularly dangerous as they are not able to ditch on the water. Especially when weather conditions initially well-suited for migration suddenly deteriorate, land birds flying offshore face the risk of being drenched by heavy rain or of suffering from exhaustion by adverse winds (Newton 2007; Diehl et al. 2014). Accidental losses during ocean-crossing in severe weather can be considerable (Newton 2007; Ward et al. 2018) and are for example assumed to account for measurable declines in some North American songbird populations (Butler 2000).

Despite the well-known phenomenon of songbird mass "fallouts" at remote islands since more than 120 years (e.g. Gätke 1895), the dimension of offshore migration, in particular of songbirds, received little scientific attention. Most knowledge on offshore land bird migration stems from studies using radar (e.g. Bruderer and Liechti 1998; Hüppop et al. 2006; Fijn et al. 2015), telemetry (e.g. Brown and Taylor 2015; Nourani et al. 2016; Kölzsch et al. 2019) or data loggers (e.g. Schmaljohann et al. 2012; Schwemmer et al. 2016; Léandri-Breton et al. 2019). These observations suggest that great amounts of land birds migrate near or along coastal margins (Williams and Williams 1990). Many birds refrain from direct crossing of water bodies, such as the Gulf of Maine (Drury and Keith 1962), the Gulf of Mexico (Zenzal et al. 2021) or the Mediterranean Sea (Bruderer and Liechti 1998), sometimes even of crossing smaller bays or straits (Nilsson and Sjöberg 2016; Brust et al. 2019; Becciu et al. 2020; Michalik et al. 2020). Some birds have even been observed to turn back to the coast after flying out to sea (Richardson 1978; Bruderer and Liechti 1998; Fortin et al. 1999; Diehl et al. 2003; Archibald et al. 2017). Coastlines may also serve as leading lines or landmarks, especially when approximately matching the desired direction of migration (van Dobben 1953; Gruys-Casimir 1964; Alerstam and Pettersson 1977; Alerstam 2001). In the light of optimal bird migration theory and of fitness consequences, the decision to cross open water versus circumventing it ("facultative barrier crossing") results from balancing time, transport costs and safety considerations (Alerstam 2001, 2011; Erni et al. 2003, 2005; Ward et al. 2018; Becciu et al. 2020). Despite the majority of land birds migrating nearshore, so-called mass migration events occur over the open sea (Russell 2005; Dierschke et al. 2011; ShamounBaranes and van Gasteren 2011). As a consequence, under suddenly deteriorating weather conditions, land birds in desperate need for shelter have been observed to accumulate and to eventually collide in masses at light vessels, platforms or ships (Newton 2007; Bocetti 2011; Ronconi et al. 2015). Songbirds have been estimated to make out up to $53-95 \%$ of collision victims at artificial offshore structures (see Hüppop et al. 2019 for a review), depending on location and type of the structure.

Out at sea, there are several methodological, technical, and/or logistical challenges to monitor bird migration (Molis et al. 2019). One major challenge particularly concerning songbirds, is their predominantly nocturnal migration (e.g. Dorka 1966; Martin 1990) and small body size. Visual observations and remote techniques such as radar, acoustic monitoring or thermal imaging all have their specific limitations concerning species covered, species determination and/ or spatial resolution (Molis et al. 2019). With these methods, it is virtually impossible to follow individuals over larger distances, e.g. to study their behavior when facing wind farms. With the recent advancement of light-weight transmitters, tracking technologies eventually overcome these limitations (Bridge et al. 2011; Katzner and Arlettaz 2020). However, to date radio-transmitters which are light enough to be carried by songbirds are dependent on nearby receivers. Hence, the detection of more than single individuals over larger areas and longer times strongly depends on the density and expansion of the receiver network. Here, we used a large-scale automated radio-telemetry array covering the German North Sea coast and islands (Brust et al. 2019; Michalik et al. 2020) to track individual flight routes of ten species of songbirds across the German Bight during autumn migration. By radio-tagging these birds at coastal stopover sites we wished to shed light on actual proportions of individuals taking offshore-oriented routes as compared to those following along the coastline in our study area.

The German Bight is a bay of approximately $77,000 \mathrm{~km}^{2}$ in the south-eastern North Sea (Central Europe) and is defined by the North Sea coasts of Denmark (north-east) and The Netherlands (south-west). Direct crossing of the German Bight in still air would take a songbird about $150 \mathrm{~km}$ in a $3.5 \mathrm{~h}$ nonstop flight (for flight speeds of different species measured by radar see Bruderer and Boldt 2001). This could offer a significant shortcut for most individuals, as roughly $85 \%$ of the migrant songbird species predominantly follow a north-east to south-west axis across northern Central Europe (Bairlein 1985; Bairlein et al. 2014). Accordingly we hypothesize that a significant share of songbirds resuming migration at coastal stopovers will take the shortcut and fly over the open sea to minimize time and energy expenditure (Alerstam 2001, 2011). Furthermore, especially those species migrating towards wintering grounds located further west of the study area should benefit from crossing the open sea while those aiming towards wintering grounds located 
towards the south should benefit most from traveling along the coast. Hence, we expect that the proportion of birds that take the shortcut over the open water is highest in west migrants and lowest in south migrants.

\section{Methods}

\section{Field methods}

During three consecutive autumn migration seasons (2017-2019), we mist-netted 362 individual passerine birds of ten species (40 Blackcaps, Sylvia atricapilla; 49 Common Blackbirds, Turdus merula; 21 Common Starlings, Sturnus vulgaris; 27 Common Whitethroats, Sylvia communis; 46 Dunnocks, Prunella modularis; 17 European Robins, Erithacus rubecula; 29 Garden Warblers, Sylvia borin; 48 Redwings, Turdus iliacus; 30 Sedge Warblers, Acrocephalus schoenobaenus; 55 Song Thrushes, Turdus philomelos). Catching took place at several coastal stopover sites in Schleswig-Holstein, Germany (Fig. 1), during

\section{(a)}

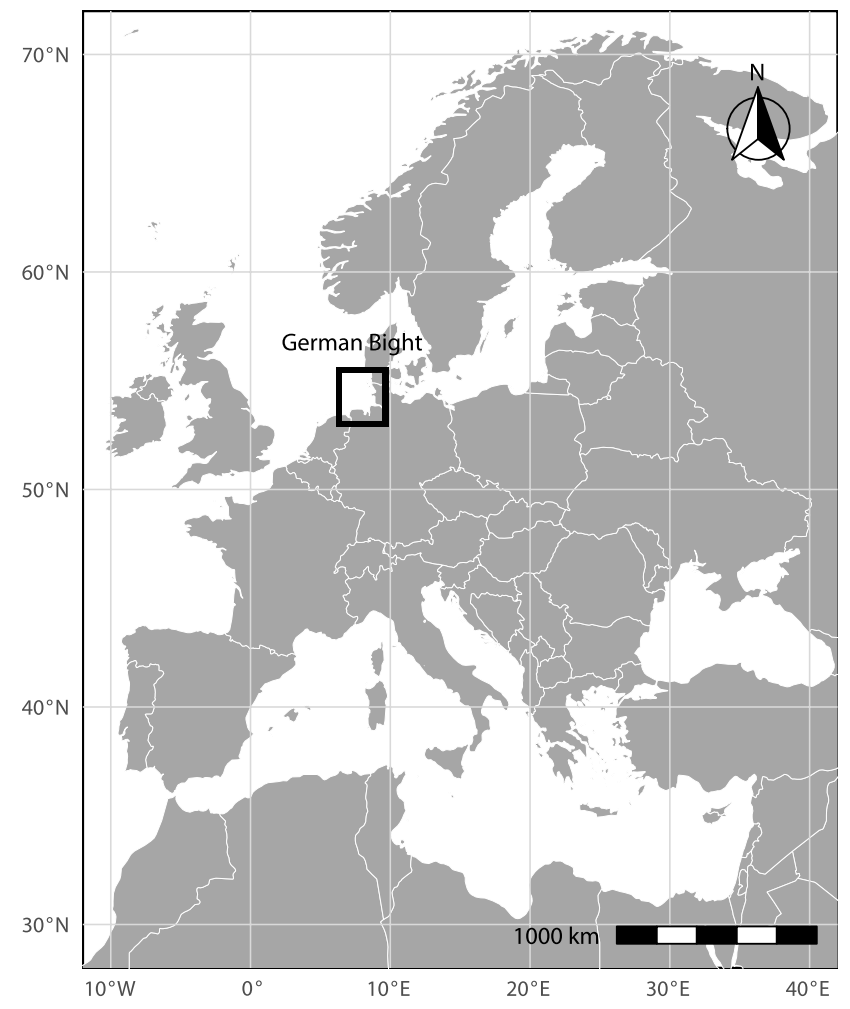

Fig. 1 a Location of the German Bight within Europe, b Geographic longitudes of individuals that were recorded during autumn as 'arrived' at the southern coast of the German Bight south of $53.9^{\circ}$ $\mathrm{N}$ or at the offshore island of Helgoland $\left(n=162\right.$, bin width $0.1^{\circ}$ ). The underlying map shows the coastline of the German Bight and its islands, as well as the locations of automated receiver stations (dots) the species' respective main migration periods in the area (26th Sept-24th Oct 2017; 3rd-17th Oct 2018; 16th-29th Aug 2019; Dierschke et al. 2011). Each bird was ringed, equipped with an individually coded radio-transmitter and released immediately afterwards. Radio-tags were attached to the back of each bird using a leg loop harness (Rappole and Tipton 1991) consisting of non-UV-resistant rubber band, which was expected to rip off after a while (Müller et al. 2018).

\section{Radio telemetry transmitters and network}

Radio transmitters used in this study were of type NTQB, manufactured by Lotek Wireless Inc. (Newmarket, ON, Canada). Each tag sends out a uniquely coded signal burst every few seconds (intervals ranging from 6 to $11 \mathrm{~s}$ ). Expected battery life of the tags ranged, depending on burst intervals, between 28 and 40 days. Both, individual signals and burst intervals are used to identify tag signatures from radio signals recorded at $150.1 \mathrm{MHz}$ at according receiver stations. Receivers are aligned to cover the coastal area as well

(b)

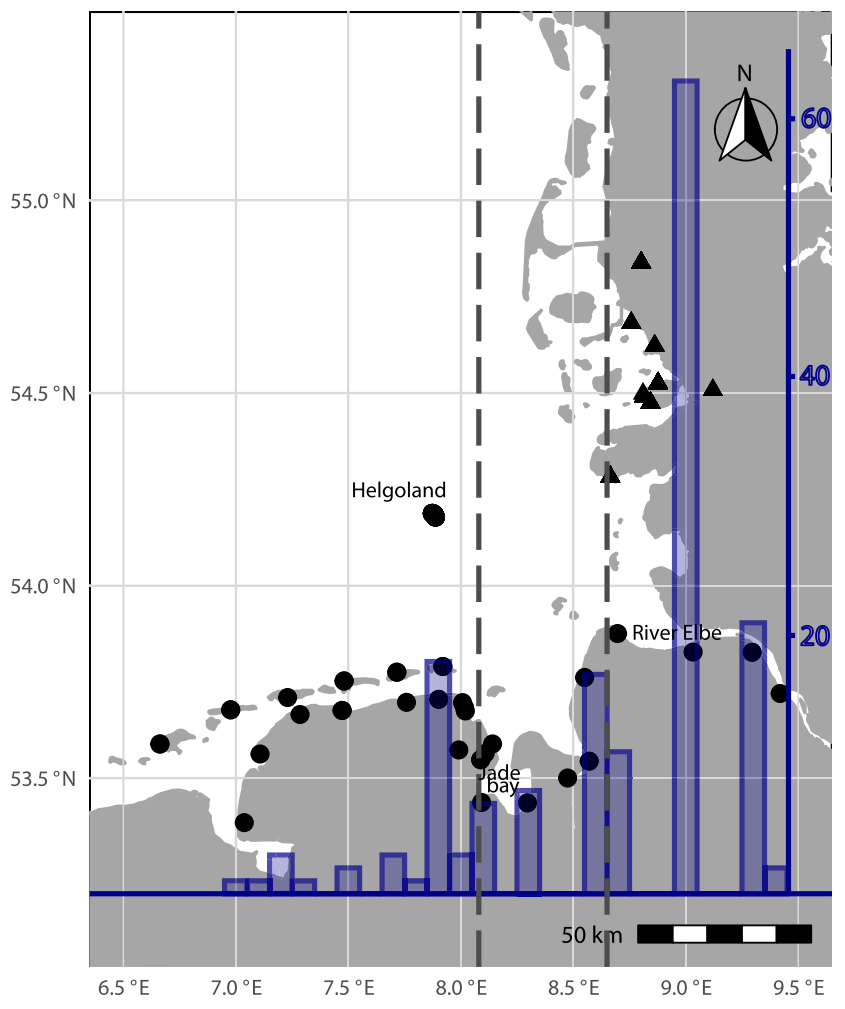

below 53.9 $\mathrm{N}$ and at Helgoland (indicated with "H") and locations of tag deployment (triangles). The vertical dashed lines (from left to right) indicate the longitude thresholds of arrivals west of the Jade bay $\left(<8.08^{\circ} \mathrm{E}\right)$ and east of the mouth of the river Elbe $\left(>8.65^{\circ} \mathrm{E}\right) .9$ additional birds 'arrived' further west at the Dutch coast (not shown in map). See motus.org for a full map of active receiver stations 
as islands of the German Bight and are part of the Motus Wildlife Tracking Network (Taylor et al. 2017, please visit https://motus.org/data/receiversMap for full details on the available receiver network throughout our study as well as detailed information of single receivers).

\section{Analyses of radio-telemetry data}

All analyses were performed using R 4.0.2 (R Core Team 2020). Tag detection data were retrieved on Sep 18th, 2020 from motus.org via the motus $\mathrm{R}$ package (Brzustowski and LePage 2018). To reduce the amount of supposable false positive detections in the data, which may arise from sources of electromagnetic noise in the surrounding of the receivers, we applied an additional automated data filtering procedure described in detail in Brust et al. (2019). Briefly, we used a subset of trustworthy and obviously false positive detections to apply binomial logistic regression models to predict each detections probability of being a false positive. Eight recording features, such as signal strength, recording continuity or temporal pattern of pulses served as fixed effects in this model. We used separate binomial logistic regression models for each season's dataset as constant technical advancements in transmitters and expansion of the receiver network impede the comparability of the recording features across the studied seasons. We defined a rather conservative probability threshold of 0.8 for detections to not be false positives, which resulted in a dataset of 160,221 detections.
We retrieved movement tracks for each individual bird from this dataset. For all birds with detections south of $53.9^{\circ}$ $\mathrm{N}$, i.e. at the island of Helgoland or at the southern part of the German or Dutch North Sea coast, we extracted individual 'arrival locations', i.e. each individuals first detection in the area (Fig. 1). If a bird had 'arrived' further west at the southern North Sea coast, i.e. west of $8.08^{\circ}$ E (Fig. 1), it had most likely migrated offshore (Brust et al. 2019; Michalik et al. 2020). 'Arrivals' further east, at the southern North Sea coast, i.e. at longitudes $>8.65^{\circ}$ (east of the mouth of the river Elbe; Fig. 1), imply alongshore movements.

In addition, to examine the effect of the species' main migration direction on the 'arrival' location, we classified each species according to its main migration direction as inferred from ringing recoveries from north-western Germany (Bairlein et al. 2014) into one of the following orientation groups: 'west migrants', 'south-west migrants', and 'south migrants' (Table 1).

\section{Statistics}

All statistical analyses were performed on the level of orientation groups. The 'arrival' longitudes were compared between orientation groups using the non-parametric Kruskal-Wallis test as the location data were on a discrete scale (i.e. fixed receiver locations) and not normally distributed. To check which groups differed, the post hoc Dunn test (Dunn 1964) was applied with a Bonferroni correction to control for the group wise error rate.

Table 1 Number of radio-tagged, detected, 'departed' and 'arrived' individuals during autumn migration per migration group and species

\begin{tabular}{|c|c|c|c|c|c|c|c|c|}
\hline \multirow{2}{*}{$\begin{array}{l}\text { Main } \\
\text { migration } \\
\text { direction }\end{array}$} & \multirow[t]{2}{*}{ Species } & \multirow{2}{*}{$\begin{array}{l}\text { Number of } \\
\text { tag deploy- } \\
\text { ments }\end{array}$} & \multirow{2}{*}{$\begin{array}{l}\text { Number of } \\
\text { detected indi- } \\
\text { viduals }\end{array}$} & \multirow{2}{*}{$\begin{array}{l}\text { Number of } \\
\text { 'departures' }\end{array}$} & \multirow{2}{*}{$\begin{array}{l}\text { Number of } \\
\text { 'arrivals' at } \\
\text { Dutch coast } \\
\left(<6.5^{\circ}\right)\end{array}$} & \multicolumn{3}{|c|}{ Number of 'arrivals' in German Bight area } \\
\hline & & & & & & $\begin{array}{l}\text { West of Jade } \\
\text { bay }\left(<8.08^{\circ}\right)\end{array}$ & $\begin{array}{l}\text { West of mouth } \\
\text { of river Elbe } \\
\left(<8.65^{\circ}\right)\end{array}$ & $\begin{array}{l}\text { East of mouth } \\
\text { of river Elbe } \\
\left(>8.65^{\circ}\right)\end{array}$ \\
\hline \multirow[t]{2}{*}{ West } & $\begin{array}{l}\text { Common } \\
\text { Blackbird }\end{array}$ & 49 & 19 & 7 & 0 & 2 & 3 & 2 \\
\hline & $\begin{array}{r}\text { Common } \\
\text { Starling }\end{array}$ & 21 & 13 & 3 & 2 & 1 & 0 & 0 \\
\hline \multirow[t]{7}{*}{ South-west } & Blackcap & 40 & 30 & 25 & 2 & 4 & 4 & 14 \\
\hline & $\begin{array}{l}\text { Common } \\
\text { Whitethroat }\end{array}$ & 27 & 23 & 23 & 1 & 2 & 3 & 16 \\
\hline & Dunnock & 46 & 33 & 19 & 0 & 2 & 1 & 14 \\
\hline & $\begin{array}{l}\text { European } \\
\text { Robin }\end{array}$ & 17 & 5 & 1 & 0 & 0 & 1 & 0 \\
\hline & Garden Warbler & 29 & 28 & 25 & 0 & 1 & 10 & 11 \\
\hline & Redwing & 48 & 37 & 27 & 4 & 8 & 2 & 13 \\
\hline & Song Thrush & 55 & 44 & 34 & 0 & 13 & 5 & 13 \\
\hline South & Sedge Warbler & 30 & 27 & 18 & 0 & 0 & 3 & 14 \\
\hline
\end{tabular}

'Departures' denote individuals that were recorded at least $50 \mathrm{~km}$ away from their respective location of tag deployment. 'Arrivals' denote individuals that were recorded at least once south of $53.9^{\circ} \mathrm{N}$ or at the offshore island of Helgoland. Numbers of 'arrived' individuals are split into geographic longitude classes (see Fig. 1 for a map) 


\section{Results}

Of the 362 birds radio-tagged during autumn migration, 259 individuals were detected by our automated receiver network (Table 1) and 'arrival locations' in the German Bight were available for 162 of these birds (Fig. 1, Table 1). Nine additional birds (two Blackcaps, two Starlings, one Whitethroat, four Redwings) 'arrived' further west at the Dutch coast (Table 1). In more detail, 57\% of the 'arrivals' were recorded by receiver stations located at the mouth of the river Elbe or further east (i.e. at geographic longitudes $>8.65^{\circ}$; Fig. 1 ), which corresponds to a southward directed movement along the coastline. Still, $25 \%$ of the 'arrivals' occurred west of the Jade bay (i.e. at

(a)

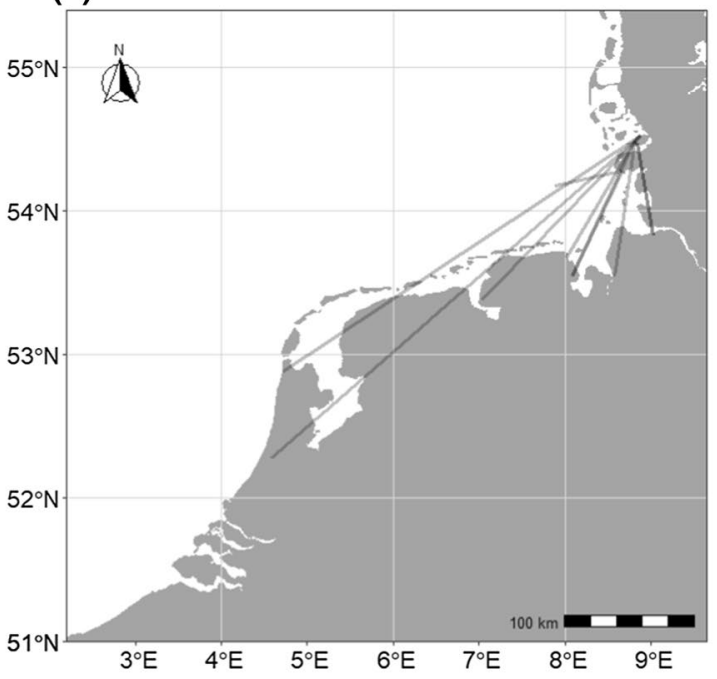

(c)

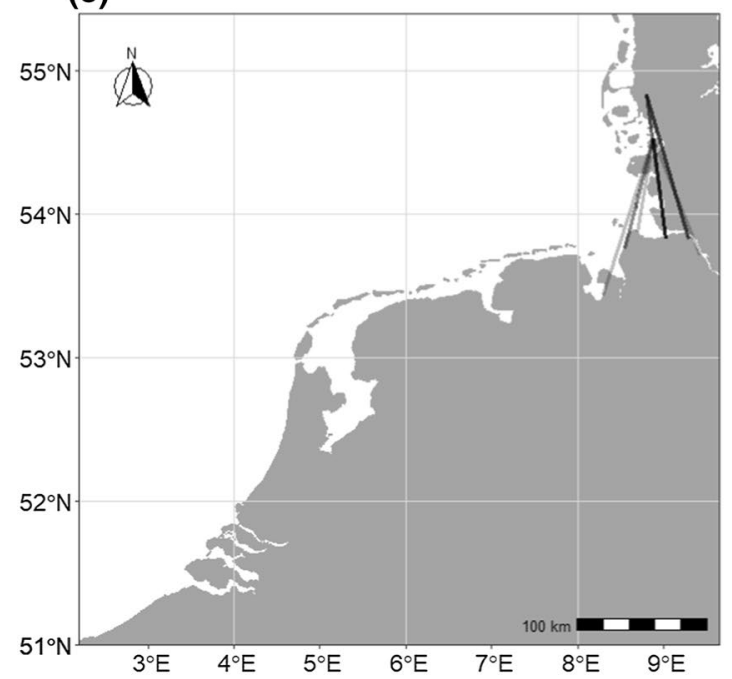

longitudes $<8.08^{\circ}$ including 'arrivals' at the Dutch coast). With regard to the chain of receivers covering the coastline (Fig. 1), birds which were not detected anywhere but west of this threshold likely flew offshore. Of these, five individuals reflecting $10 \%$ of west migrants and $2.8 \%$ of southwest migrants were indeed detected by receivers at the offshore island of Helgoland (one Blackbird, one Blackcap, one Redwing, one Song Thrush, one Whitethroat).

Out of the individuals which 'arrived' at geographic longitudes $>8.65^{\circ} 23 \%$ were last recorded west of their 'arrival' location, indicating circumvention rather than a crossing of the German Bight. Of these, only one individual was grouped as a 'south migrant'. This is also reflected in the mean migration direction of the three migration groups: 'West migrating' birds had a mean migration direction in

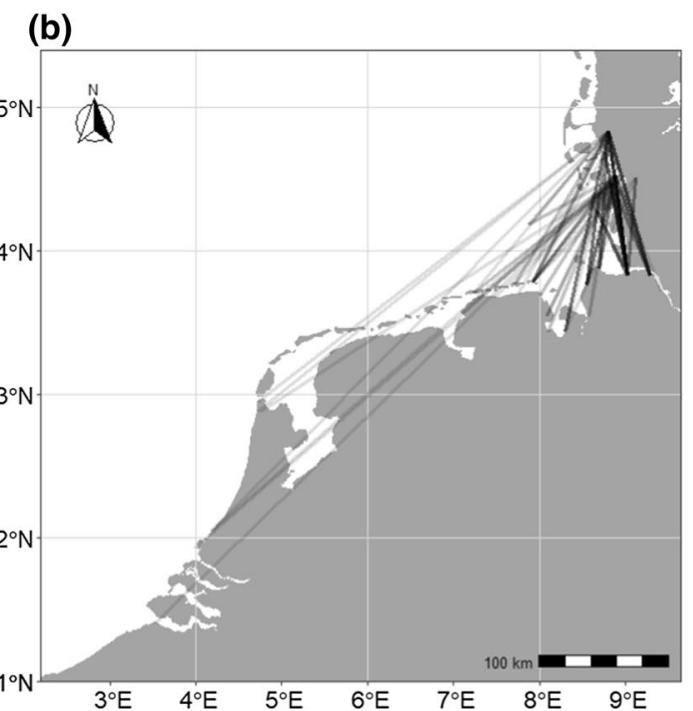


the German Bight area of $215^{\circ}$ (Rayleigh test: rho $=0.89$, $p<0.001, n=10$; Fig. 2a). The mean direction angle of 'south-west migrants' was $192^{\circ}$ (Rayleigh test: rho $=0.91$, $p<0.001, n=154$; Fig. $2 \mathrm{~b}$ ) and 'south migrants' headed in a mean direction of $176^{\circ}$ (Rayleigh test: rho $=0.97, p<0.001$, $n=18$; Fig. 2c).

In addition to the overall migration directions, the distributions of longitudes of the 'arrival locations' differed between the orientation groups (Kruskal-Wallis test: $X^{2}=13.57, d f=2, p=0.001$ ), specifically between 'west' and 'south migrants' (Dunn post-hoc test: $Z=3.61, p_{\text {adj }}<0.001$ ), as well as between 'south-west' and 'south migrants' (Dunn post-hoc test $Z=2.68, p_{\text {adj }}=0.022$ ). 'West migrants' arrived on average at geographic longitudes $<8.08^{\circ}$ (median $=8.05^{\circ}$, range $4.59^{\circ}-9.03^{\circ}$; Fig. 3 ) indicating mainly offshore flights, whereas, 'south migrants' 'arrived' on average at geographic longitudes $>8.65^{\circ}\left(\right.$ median $=9.03^{\circ}$, range $8.3^{\circ}-9.42^{\circ}$; Fig. 3), suggesting that they had predominantly followed the coastline due south. 'South-west' migrants also 'arrived' on average at geographic longitudes $>8.65^{\circ}$ but varied more than the other two groups (median $=8.7^{\circ}$, range $3.52^{\circ}-9.42^{\circ}$; Fig. 3). Redwings and Song Thrushes had the highest proportions of offshore flying individuals among the 'southwest' migrants (i.e. 12 of 27 and 13 of 31, respectively; Table 1).

\section{Discussion}

We radio-tracked individual flight routes of ten species of songbirds migrating over a marine bight. A remarkable proportion of one quarter of the tracked birds resuming migration from the coast actually took the shortcut across the German Bight. As expected, the proportion of offshore

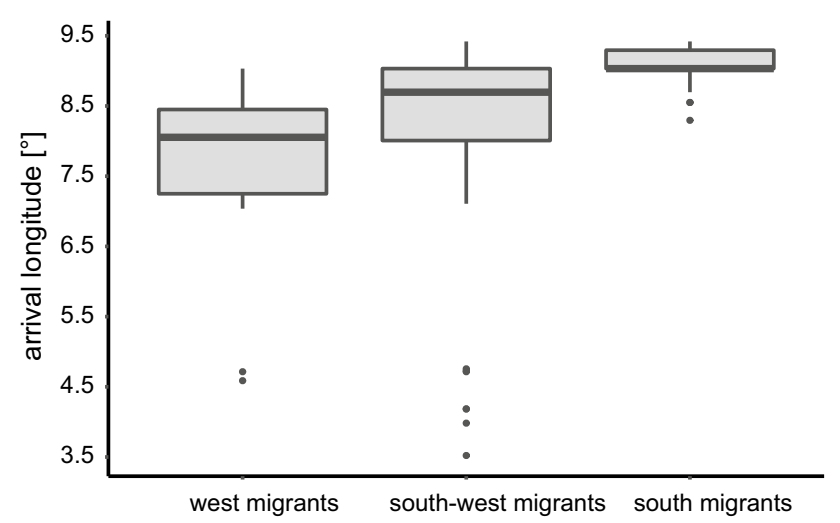

Fig. 3 Tukey style box and whisker plot of geographic longitudes of 'west migrants' $(n=10)$, 'south-west migrants' $(n=144)$ and 'south migrants' $(n=17)$ representing the 'arrival' at south of $53.9^{\circ} \mathrm{N}$ or at the offshore island Helgoland during autumn migration migrating individuals was higher in species with more westerly migratory destinations.

Our study provides, for the first time, a quantification of the proportions of offshore flying individuals among a variety of songbird migrants. The found overall ratio of offshore migrating birds is probably an underestimate, as data might have been biased due to the geometry of our receiver array. As our receivers are mainly covering the coastlines and nearshore islands of the south-eastern North Sea, the likelihood of detecting a flying radio-tagged bird decreases to the west. It is known from observations and constant bird ringing at the offshore island Helgoland that migrating songbirds cross the German Bight in huge numbers (Dierschke et al. 2011). Still, from these numbers, the ratio of offshore flying birds cannot be assessed as numbers of individuals actually departing from the coast are missing. Our study adds quantitative information to this apparent gap of knowledge by providing a rough but nonetheless reliable estimate of the scale of songbird offshore migration. In addition, our results quantitatively confirm previous visual and radar observations of coastal migration being more pronounced in the German Bight area as compared to offshore migration (Hüppop et al. 2006, 2010), which also fits well with globally observed bird migration patterns (e.g. Williams and Williams 1990). This finding is especially interesting as all except one of the species investigated here are mainly nocturnal migrants, which have often been described to be less sensitive to the overflown landscape as compared to diurnal migrants (Lack 1963; Eastwood 1967; Bruderer and Liechti 1998; Diehl et al. 2003). The coastlines still seem to have a leading line effect for nocturnal migrants, too (Buurma 1995; Brust et al. 2019; Michalik et al. 2020), which has also been observed in other regions (Richardson 1978).

In line with our hypothesis, the observed proportion of offshore migrating individuals was not equally distributed among the studied species, but largely depended on the species-specific overall direction of migration. Designated west migrants, Common Blackbirds and Common Starlings (Bairlein et al. 2014), were more prone to fly offshore compared to predominantly south migrating Sedge Warblers (Bairlein et al. 2014). We assume that offshore migrating individuals, especially in the group of west migrants, were underrepresented in our dataset. The number of individuals that were detected at least $50 \mathrm{~km}$ away from their tag deployment location ('departed' individuals in Table 1) was noticeably low in both west migrating species as compared to other investigated species. Even though in Blackbirds and Starlings, we cannot exclude that some of the tagged individuals might have wintered in the area (Bairlein et al. 2014), the number of individuals detected over longer times in close proximity to their tagging sites was comparatively low. In addition, other investigated species such as Redwings and (though in far lower numbers) Dunnocks are also known to winter in 
our study area (Bairlein et al. 2014), but their departure rates were much higher. It thus seems very likely that the observed bias in departure and arrival numbers between the species groups arose from our predominantly coastal array of receivers where individuals departing in westerly directions from their coastal stopover sites were probably missed due to the lower number of offshore receivers.

Still and despite this apparent gap in our receiver array, we were able to detect differences in proportions of offshore migrating individuals between the migration groups. We propose that the actual effect might be even more pronounced than we are able to show from our limited dataset. In order to reach their wintering destinations in an optimized way (Alerstam 2001, 2011), west migrants should profit most from taking the shortcut across the German Bight when compared to the other migration groups. This is also reflected by observations of thousands of individuals of these species passing (Hüppop et al. 2010) or resting on Helgoland (Dierschke et al. 2011) during migration each year. West migrating songbirds might consequently have a higher risk than other species or species groups of being affected by artificial offshore structures in the German Bight. This suggestion is supported by the relatively high proportions of Blackbirds and Starlings among carcasses found at the offshore platform FINO 1 (Hüppop et al. 2016).

The vast majority of songbirds migrate, however, in a south-westerly direction through our study area (Bairlein 1985; Bairlein et al. 2014). This group seems rather inhomogeneous as we observed huge variation in their 'arrival' locations. Among the group of south-west migrants, the two investigated thrush species Redwing and Song Thrush both had comparatively high proportions of offshore migrating individuals (Brust et al. 2019). Long-term observations of resting songbird migrants on Helgoland may lead to the impression of offshore migration being much more pronounced in the two thrush species than in the two warblers, for example, due to the large differences in their total numbers resting on Helgoland during their respective migration peaks (i.e. mean 5-day-maxima of bird counts of roughly 1000 for the thrushes vs. roughly 100 for the warblers; Dierschke et al. 2011). Without reference to the originating biogeographic population sizes of migrants passing the island, however, conclusions have to be drawn with caution. Our results substantiate this suggestion for the first time, as they are based on a known number of birds departing from the mainland.

Redwings and Song Thrushes were among the most abundant songbird species registered and found dead at offshore platforms in the German Bight (Müller 1981; Hüppop et al. 2006, 2012, 2016). These findings suggest a relatively high attraction of thrushes by artificial offshore structures (Hüppop and Hilgerloh 2012; Hüppop et al. 2016). Potential impacts, especially of offshore wind energy turbines on bird populations are debated in this context (Fox et al. 2006; Stewart et al. 2007; Arnold and Zink 2011; Hüppop et al. 2019). Besides direct measurement of collisions, lack of information remains a key problem for population risk assessment. Gathering more datasets like ours will help to estimate the ratios of birds flying offshore vs. alongshore, which is necessary to eventually estimate possible population effects (Fox et al. 2006; Brabant et al. 2015) and to take mitigation measures.

While the species routings to a certain extent were determined by their species-specific main migration direction, individual arrival longitudes varied widely. The prevailing weather conditions, mostly prominently wind, are well-known to influence taken routes of migratory songbirds (e.g. Cochran and Kjos 1985, Horton et al. 2016, Sinelschikova et al. 2020). A previous study analyzing the thrush data included in this study found offshore flights mainly under easterly and/or generally weaker wind regimes (Brust et al. 2019). This finding points towards an active decision for suitable weather conditions and accordingly taken routes rather than passive effects like drift (Cochran and Kjos 1985; Sinelschikova et. al. 2020). Besides the notion of many offshore flying individuals in the group of south-west migrants, we recorded a high proportion of individuals that had most likely circumvented the German Bight. In addition to environmental cues such as weather, intrinsic factors like fuel load (Alerstam 2001; Schmaljohann et al. 2013) and other physiological conditions (Eikenaar et al. 2018; Hegemann et al. 2019) take influence on the routes taken by individual birds. A good physical shape allows longer offshore flights, while individuals in less good condition are more likely to stay in closer proximity to the coast (Schmaljohann and NaefDaenzer 2011). Accordingly, it is the sum of a variety of factors, including the specific migratory goal as well as prevailing environmental conditions and inner state leading an individual towards taking a specific route during migration.

To conclude, although our study confirmed the general notion of (song)bird migration accumulating near the coast, it revealed a considerable proportion of individuals migrating offshore after departure from their coastal stopover sites during autumn. West migrants were particularly prone to fly offshore. But also south-west migrating species, especially thrushes, showed high proportions of individuals migrating offshore. Our study sheds light on why some species or species groups, such as Starlings or Thrushes, might be more prone to be affected by the ongoing increase of artificial offshore structures than others. The general propensity of a species for offshore flights, however, could only partly be explained by its main migration direction. The, hopefully, ongoing expansion of the Motus Wildlife Tracking System (Taylor et al. 2017) will 
facilitate future investigation of intrinsic and environmental factors driving songbird offshore migration.

Acknowledgements We thank the German Federal Agency for Nature Conservation (BfN) for its financial support. We are grateful to the numerous hosts of our radio-receiver stations and additional data points gathered at Motus receivers of Sander Lagerveld's and Heiko Schmaljohann's working groups. Among the many helpers during the fieldwork, we especially thank Andreas Michalik, Felix Weiß, Melanie Weper and Jonas Wobker. We also thank Heinz-Hinrich Blikslager, Mario de Neidels, Thomas Mertens and Timo Ubben for their valuable technical assistance.

Author contributions $\mathrm{OH}$ acquired the funding for this project. Both authors contributed to the study conception, contributed on writing the manuscript and read and approved its final version.

Funding Open Access funding enabled and organized by Projekt DEAL. This project was funded by the German Federal Agency for Nature Conservation (BfN, Grant numbers 351582210A, 351986140A to $\mathrm{OH})$.

Data availability Radio-telemetry data will be available at movebank. org upon acceptance of this manuscript.

\section{Declarations}

Conflicts of interest The authors have no financial or proprietary interests in any material presented and discussed in this article.

Ethics approval Experimental procedures were approved by the Ministry of Energy Transition, Agriculture, Environment, Nature and Digitalization (MELUND) Schleswig-Holstein, Germany, license number V244-69134/2016(92-8/16).

Open Access This article is licensed under a Creative Commons Attribution 4.0 International License, which permits use, sharing, adaptation, distribution and reproduction in any medium or format, as long as you give appropriate credit to the original author(s) and the source, provide a link to the Creative Commons licence, and indicate if changes were made. The images or other third party material in this article are included in the article's Creative Commons licence, unless indicated otherwise in a credit line to the material. If material is not included in the article's Creative Commons licence and your intended use is not permitted by statutory regulation or exceeds the permitted use, you will need to obtain permission directly from the copyright holder. To view a copy of this licence, visit http://creativecommons.org/licenses/by/4.0/.

\section{References}

Alerstam T (2001) Detours in bird migration. J Theor Biol 209:319_ 331. https://doi.org/10.1006/jtbi.2001.2266

Alerstam T (2011) Optimal bird migration revisited. J Ornithol 152:523. https://doi.org/10.1007/s10336-011-0694-1

Alerstam T, Pettersson S-G (1977) Why do migrating birds fly along coastlines? J TheorBiol 65:699-712. https://doi.org/10.1016/ 0022-5193(77)90016-9

Archibald KM, Buler JJ, Smolinsky JA, Smith RJ (2017) Migrating birds reorient toward land at dawn over the Great Lakes, USA. Auk 134:193-201. https://doi.org/10.1642/AUK-16-123.1
Arnold TW, Zink RM (2011) Collision mortality has no discernible effect on population trends of North American birds. PLoS ONE 6:e24708. https://doi.org/10.1371/journal.pone.0024708

Bairlein F (1985) Offene Fragen der Erforschung des Zuges paläarktischer Vogelarten nach Afrika. Vogelwarte 33:144-155

Bairlein F, Dierschke J, Dierschke V, Salewski V, Geiter O, Hüppop K, Köppen U, Fiedler W (2014) Atlas des Vogelzugs: Ringfunde deutscher Brut- und Gastvögel. AULA-Verlag, Wiebelsheim

Becciu P, Rotics S, Horvitz N, Kaatz M, Fiedler F, Zurell D, Flack A, Jeltsch F, Wikelski M, Nathan R, Sapir N (2020) Causes and consequences of facultative sea crossing in a soaring migrant. Funct Ecol 34:840-852. https://doi.org/10.1111/1365-2435.13539

Bocetti CI (2011) Cruise ships as a source of avian mortality during fall migration. Wilson J Ornithol 123:176-178. https://doi.org/ 10.1676/09-168.1

Brabant R, Vanermen N, Stienen EWM, Degraer S (2015) Towards a cumulative collision risk assessment of local and migrating birds in North Sea offshore wind farms. Hydrobiologia 756:63-74. https://doi.org/10.1007/s10750-015-2224-2

Bridge ES, Thorup K, Bowlin MS, Chilson PB, Diehl RH, Fléron RW, Hartl P, Kays R, Kelly JF, Robinson WD, Wikelski M (2011) Technology on the move: recent and forthcoming innovations for tracking migratory birds. Bioscience 61:689-698. https://doi.org/ 10.1525/bio.2011.61.9.7

Brown JM, Taylor PD (2015) Adult and hatch-year blackpoll warblers exhibit radically different regional-scale movementsduring postfledgling dispersal. Biol Lett 11:12. https://doi.org/10.1098/rsbl. 2015.0593

Bruderer B, Boldt A (2001) Flight characteristics of birds: I. Radar measurements of speeds. Ibis 143:178-204. https://doi.org/10. 1111/j.1474-919X.2001.tb04475.x

Bruderer B, Jenni L (1990) Migration across the alps. In: Gwinner E (ed) Bird migration. Springer, Berlin, pp 60-77

Bruderer B, Liechti F (1998) Flight behaviour of nocturnally migrating birds in coastal areas - crossing or coasting. J Avian Biol 29:499-507. https://doi.org/10.2307/3677169

Brust V, Michalik B, Hüppop O (2019) To cross or not to cross thrushes at the German North Sea coast adapt flight and routing to wind conditions in autumn. Mov Ecol 7:32. https://doi.org/10. 1186/s40462-019-0173-5

Brzustowski J, LePage D (2018) Motus: fetch and use data from the Motus Wildlife Tracking System. R package version 1.0.0

Butler RW (2000) Stormy seas for some North American songbirds: are declines related to severe storms during migration? Auk 117:518522. https://doi.org/10.1093/auk/117.2.518

Buurma LS (1995) Long-range surveillance radars as indicators of bird numbers aloft. Israel J Ecol Evol 41:221-236. https://doi.org/10. 1080/00212210.1995.10688795

Chapman BB, Hulthen K, Wellenreuther M, Hansson L-A, Nilsson J-Å, Brönmark C (2014) Patterns of animal migration. In: Hansson L-A, Åkesson S (eds) Animal movement across scales. Oxford University Press, Oxford, pp 11-35

Cochran WW, Kjos CG (1985) Wind drift and migration of thrushes: a telemetry study. Nat Hist Surv Bull 33:297-330

Cohen EB, Barrow WC, Buler JJ, Deppe JL, Farnsworth A, Marra PP, McWilliams DW, Wilson RR, Woodreyand MS, Moore FR (2017) How do en route events around the Gulf of Mexico influence migratory landbird populations? Condor 119:327-343. https:// doi.org/10.1650/CONDOR-17-20.1

Diehl RH, Larkin RP, Black JE (2003) Radar observations of bird migration over The Great Lakes. Auk 120:278-290. https://doi. org/10.1093/auk/120.2.278

Diehl RH, Bates JM, Willard DE, Gnoske TP (2014) Bird mortality during nocturnal migration over Lake Michigan: a case study. Wilson J Ornithol 126:19-29. https://doi.org/10.1676/12-191.1 
Dierschke J, Dierschke V, Hüppop K, Hüppop O, Jachmann KF (2011) Die Vogelwelt der Insel Helgoland. OAG Helgoland, Helgoland

Dolnik VR (1990) Bird Migration across arid and mountainous Regions of Middle Asia and Kasakhstan. In: Gwinner E (ed) Bird migration. Springer, Berlin, pp 368-386

Dorka V (1966) Das jahres- und tageszeitliche Zugmuster von Kurzund Langstreckenziehern nach Beobachtungen auf den Alpenpässen Cou/Bretolet (Wallis). Ornithol Beob 63:165-222

Drury WH, Keith JA (1962) Radar studies of songbird migration in coastal New England. Ibis 104:449-489. https://doi.org/10.1111/j. 1474-919X.1962.tb08681.x

Dunn OJ (1964) Multiple comparisons using rank sums. Technometrics 6:241-252. https://doi.org/10.2307/1266041

Eastwood E (1967) Radar ornithology. The Chaucer Press, Bungay

Eikenaar C, Isaksson C, Hegemann A (2018) A hidden cost of migration? Innate immune function versus antioxidant defense. Ecol Evol 8:2721-2728. https://doi.org/10.1002/ece3.3756

Erni B, Liechtig F, Bruderer B (2003) How does a first year passerine migrant find its way? Simulating migration mechanisms and behavioural adaptations. Oikos 103:333-304. https://doi.org/ 10.1034/j.1600-0706.2003.12176.x

Erni B, Liechtig F, Bruderer B (2005) The role of wind in passerine migration between Europe and Africa. Behav Ecol 16:732-740. https://doi.org/10.1093/beheco/ari046

Fijn RC, Krijgsveld KL, Poot MJM, Dirksen S (2015) Bird movements at rotor heights measured continuously with vertical radar at a Dutch offshore wind farm. Ibis 157:558-566. https://doi. org/10.1111/ibi.12259

Fortin D, Liechti F, Bruderer B (1999) Variation in the nocturnal flight behaviour of migratory birds along the northwest coast of the Mediterranean Sea. Ibis 141:480-488. https://doi.org/10. 1111/j.1474-919X.1999.tb04417.x

Fox AD, Desholm M, Kahlert J, Christensen TK, Petersen IK (2006) Information needs to support environmental impact assessment of the effects of European marine offshore wind farms on birds. Ibis 148:129-144. https://doi.org/10.1111/j.1474-919X.2006. 00510.x

Gätke H (1895) Heligoland as an ornithological observatory: the result of fifty years' experience. D. Douglas, Edinburgh

Gruys-Casimir EM (1964) On the influence of environmental factors on the autumn migration of chaffinch and starling: a field study. Arch Néerlandaises de Zoologie 16:175-279. https://doi.org/10. 1163/036551665X00012

Hegemann A, Fudickar AM, Nilsson J-Å (2019) A physiological perspective on the ecology and evolution of partial migration. J Ornithol 160:893-905. https://doi.org/10.1007/s10336-019-01648-9

Horton K, Van Doren B, Stepanian P, Hochachja WM, Farnsworth A, Kelly JF (2016) Nocturnally migrating songbirds drift when they can and compensate when they must. Sci Rep 6:21249. https:// doi.org/10.1038/srep21249

Hüppop O, Hilgerloh G (2012) Flight call rates of migrating thrushes: effects of wind conditions, humidity and time of day at an illuminated offshore platform. J Avian Biol 43:85-90. https://doi.org/ 10.1111/j.1600-048X.2011.05443.x

Hüppop O, Dierschke J, Exo K-M, Fredrich E, Hill R (2006) Bird migration studies and potential collision risk with offshore wind turbines. Ibis 148:90-109. https://doi.org/10.1111/j.1474-919X. 2006.00536.x

Hüppop K, Dierschke J, Dierschke V, Hill R, Jachmann KF, Hüppop O (2010) Phänologie des "sichtbaren" Vogelzugs über der Deutschen Bucht. Vogelwarte 48:181-267

Hüppop K, Dierschke J, Hill R, Hüppop O (2012) Jahres- und tageszeitliche Phänologie der Vogelrufaktivität über der Deutschen Bucht. Vogelwarte 50:87-108
Hüppop O, Hüppop K, Dierschke J, Hill R (2016) Bird collisions at an offshore platform in the North Sea. Bird Study 63:73-82. https:// doi.org/10.1080/00063657.2015.1134440

Hüppop O, Michalik B, Bach L, Hill R, Pelletier SK (2019) Migratory birds and bats. In: Perrow MR (ed) Wildlife and wind farms, conflicts and solutions, vol 3. Offshore: Potential effects. Pelagic Publishing, Exeter, pp 142-173

Katzner TE, Arlettaz R (2020) Evaluating contributions of recent tracking-based animal movement ecology to conservation management. Front Ecol Evol 24:519. https://doi.org/10.3389/fevo. 2019.00519

Klaassen RHG, Hake M, Strandberg R, Koks BJ, Trierweiler C, Exo K-M, Bairlein F, Alerstam T (2014) When and where does mortality occur in migratory birds? Direct evidence from long-term satellite tracking of raptors. J Anim Ecol 83:176-184. https://doi. org/10.1111/1365-2656.12135

Kölzsch A, Müskens GJDM, Szinai P, Moonen S, Glazov P, Kruckenberg H, Wikelski M, Nolet BA (2019) Flyway connectivity and exchange primarily driven by moult migration in geese. Mov Ecol 7:3. https://doi.org/10.1186/s40462-019-0148-6

La Sorte FA, Fink D (2017) Migration distance, ecological barriers and en-route variation in the migratory behaviour of terrestrial bird populations. Glob Ecol Biogeogr 26:216-227. https://doi. org/10.1111/geb.12534

Lack D (1963) Migration across the southern North Sea studied by radar. Part 4. Autumn Ibis 105:1-54. https://doi.org/10.1111/j. 1474-919X.1963.tb02473.x

Lack D, Lack E (1951) Migration of insects and birds through a Pyrenean pass. J Anim Ecol 20:63-67. https://doi.org/10.2307/1644

Léandri-Breton D-J, Lamarre J-F, Bêty J (2019) Seasonal variation in migration strategies used to cross ecological barriers in a nearctic migrant wintering in Africa. J Avian Biol. https://doi.org/10. 1111/jav.02101

Martin GR (1990) The visual problems of nocturnal migration. In: Gwinner E (ed) Bird migration: physiology and ecophysiology. Springer, Berlin, pp 185-197

Michalik B, Brust V, Hüppop O (2020) Are movements of daytime and nighttime passerine migrants as different as day and night? Ecol Evol 10:11031-11042. https://doi.org/10.1002/ece3.6704

Molis M, Hill R, Hüppop O, Bach L, Coppack T, Pelletier SK, Dittmann T, Schulz A (2019) Measuring bird and bat collision and avoidance. In: Perrow MR (ed) Wildlife and windfarms, conflicts and solutions, vol 4. Offshore: Monitoring and mitigation. Pelagic Publishing, Exeter, pp 167-206

Müller HH (1981) Vogelschlag in einer starken Zugnacht auf der Offshore-Forschungsplattform 'Nordsee' im Oktober 1979. Seevögel 2:33-37

Müller F, Rüppel G, Schmaljohann H (2018) Does the length of the night affect the timing of nocturnal departures in a migratory songbird? Anim Behav 141:183-194. https://doi.org/10.1111/ 1365-2656.12821

Newton I (2007) Weather-related mass-mortality events in migrants. Ibis 149:453-467. https://doi.org/10.1111/j.1474-919X.2007. 00704.x

Nilsson C, Sjöberg S (2016) Causes and characteristics of reverse bird migration: an analysis based on radar, radio tracking and ringing at Falsterbo, Sweden. J Avian Biol 47:354-362. https://doi.org/ 10.1111/jav.00707

Nilsson C, Dokter AM, Verlinden L, Shamoun-Baranes J, Schmid B, Desmet P, Bauer S, Chapman J, Alves JA, Stepanian PM, Sapir N, Wainwright C, Boos M, Górska A, Menz MHM, Rodrigues P, Leijnse H, Zehtindjiev P, Brabant R, Haase G, Weisshaupt N, Ciach M, Liechti F (2019) Revealing patterns of nocturnal migration using the European weather radar network. Ecography 42:876-886. https://doi.org/10.1111/ecog.04003 
Nourani E, Yamaguchi NM, Manda A, Higuchi H (2016) Wind conditions facilitate the seasonal water-crossing behaviour of Oriental Honey-buzzards Pernisptilorhynchus over the East China Sea. Ibis 158:506-518. https://doi.org/10.1111/ibi.12383

R Core Team (2020) R: a language and environment for statistical computing. R Foundation for Statistical Computing, Vienna

Rappole JH, Tipton AR (1991) New harness design for attachment of radio transmitters to small passerines. J Field Ornithol 62:335-337

Richardson WJ (1978) Reorientation of nocturnal landbird migrants over the Atlantic Ocean near Nova Scotia in autumn. Auk 95:717732. https://doi.org/10.1093/auk/95.4.717

Ronconi RA, Allard KA, Taylor PD (2015) Bird interactions with offshore oil and gas platforms: review of impacts and monitoring techniques. J Environ Manag 147:34-45. https://doi.org/10.1016/j. jenvman.2014.07.031

Russell RW (2005) Interactions between migrating birds and offshore oil and gas platforms in the Northern Gulf of Mexico. US Department of the Interior, Minerals Management Service, Gulf of Mexico OCS Region OCS Study MMS 2005-009

Schmaljohann H, Naef-Daenzer B (2011) Body condition and wind support initiate the shift of migratory direction and timing of nocturnal departure in a songbird. J Anim Ecol 80:1115-1122. https:// doi.org/10.1111/j.1365-2656.2011.01867.x

Schmaljohann H, Fox JW, Bairlein F (2012) Phenotypic response to environmental cues orientation and migration costs insongbirds flying halfway around the world. Anim Behav 84:623-640. https:// doi.org/10.1016/j.anbehav.2012.06.018

Schmaljohann H, Liechti F, Bruderer B (2007) Songbird migration across the Sahara: the non-stop hypothesis rejected! Proc R Soc B Biol 274:735-739. https://doi.org/10.1098/rspb.2006.0011

Schmaljohann H, Korner-Nievergelt F, Naef-Daenzer B, Nagel R, Maggini I, Bulte M, Bairlein F (2013) Stopover optimization in a longdistance migrant: the role of fuel load and nocturnal take-off time in Alaskan northern wheatears (Oenantheoenanthe). Front Zool 10:26. https://doi.org/10.1186/1742-9994-10-26

Schwemmer P, Enners L, Garthe S (2016) Migration routes of Eurasian Curlews (Numeniusarquata) resting in the eastern Wadden Sea based on GPS telemetry. J Ornithol 157:901-905. https://doi.org/ 10.1007/s10336-016-1338-2
Shamoun-Baranes J, van Gasteren H (2011) Atmospheric conditions facilitate mass migration events across the North Sea. Anim Behav 81:691-704. https://doi.org/10.1016/j.anbehav.2011.01.003

Sinelschikova A, Vorotkov M, Bulyuk V, Bolshakov C (2020) Compensation for wind drift in the nocturnally migrating Song Thrushes in relation to altitude and wind. Behav Proc 177(2020):104154. https://doi.org/10.1016/j.beproc.2020.104154

Stewart GB, Pullin AS, Coles CF (2007) Poor evidence-base for assessment of windfarm impacts on birds. Environ Conserv 34:1-11. https://doi.org/10.1017/S0376892907003554

Taylor P, Crewe T, Mackenzie S, Lepage D, Aubry Y, Crysler Z, Finney G, Francis C, Guglielmo C, Hamilton D, Holberton R, Loring PH, Mitchell GW, Norris D, Paquet J, Ronconi RA, Smetzer J, Smith PA, Welch LJ, Woodworth BK (2017) The Motus Wildlife Tracking System: a collaborative research network to enhance the understanding of wildlife movement. Avian Conserv Ecol 12:8. https://doi.org/10.5751/ACE-00953-120108

van Dobben WH (1953) Bird migration in The Netherlands. Ibis 95:212-234. https://doi.org/10.1111/j.1474-919X.1953.tb00686.x

Ward MP, Benson TJ, Deppe J, Zenzal TJ, Diehl RH, Celis-Murillo A, Bolus R, Moore FR (2018) Estimating apparent survival of songbirds crossing the Gulf of Mexico during autumn migration. Proc R Soc B 285:20181747. https://doi.org/10.1098/rspb.2018.1747

Williams TC, Williams JM (1990) Open ocean bird migration. IEEE Proc F (Radar Signal Process) 137:133-138. https://doi.org/10. 1049/ip-f-2.1990.0019

Zenzal TJ, Ward MP, Diehl RH, Buler JJ, Smolinsky J, Deppe JL, Bolus RT, Celis-Murillo A, Moore FR (2021) Retreat, detour or advance? Understanding the movements of birds confronting the Gulf of Mexico. Oikos 130:739-752. https://doi.org/10.1111/oik. 07834

Publisher's Note Springer Nature remains neutral with regard to jurisdictional claims in published maps and institutional affiliations. 